\title{
OPERATIONAL RISK MANAGEMENT AND CUSTOMER COMPLAINTS IN OMANI BANKS
}

\author{
Rawan Khamis AL-kiyumi', Zamzam Nasser AL-hattali1', Essia Ries Ahmed11, \\ ${ }^{1}$ College of Economics, Management and Information Systems, University of Nizwa, Oman.
}

ABSTRACT - The aim of this research is to analyze the relationship between operational risk management and customer complaints in Omani banks. Initially, the current research carried out a quantitative approach on the concepts which connect the variables of the current research, where the data have been collected via a survey on commercial banks in Oman. The findings demonstrate that the operational risk management has a negative and significant link with customer complaints due to there is a proper manner in dealing with risks. On the other hand, the findings revealed that there is a negative impact on absence to deal with risks facing Omani banks. Also, it has been noted that in the event of an increase in operational risk management, customers' complaints are decreased. The current research has added a value and notable contribution lies in its elucidation for the importance of the impact of operational risk management on customer complaints in Omani banks.

\author{
ARTICLE HISTORY \\ Received: 12-10-2021 \\ Revised: 12-11-2021 \\ Accepted: $29-11-2021$
}

\section{KEYWORDS}

Operational Risk

Management

Customers Complaints

Banks

Oman

\section{INTRODUCTION}

Operational risk management is considered as a one of the most issues for financial institutions, especially in banks (Ahmed, Alabdullah, Shaharudin, \& Putri, 2020). In light of the development of the economic environment, operational risks have become an indispensable part of banks, especially the increase in the volume of banking transactions (Alfadhl \& Alabdullah, 2016; Alabdullah \& Ahmed, 2018; Alabdullah, Ahmed, \& Abushammala, 2020). In addition, customer complaints are considered to be very important daily problems facing banks. It considered a core indicator of financial performance, customer satisfaction, and the number of new commercial bank clients (Rahim, Ahmed, Sarkawi, Jaaffar, \& Shamsuddin, 2019; Uddin, Khan, \& Mohammad, 2015; Uddin, Khan, \& Farhana, 2014). Banks at present have faced various risks and thus it is one of the biggest concern is managing and controlling these risks. Many customers working in the bank do not know how to manage these risks, and the more complex in the banking business, the higher the operational risk (Chernobai, Ozdagli, \& Wang, 2021; Ahmed, Amran, \& Islam, 2018). Banks may face misappropriation of public funds at the hands of their employees. Also there is a risk of fraudulent securities, such as bonds, checks, and important documents held by financial institutions (Alabdullah, 2016; Alabdullah, 2019; Alabdullah, Ahmed, \& Nor, 2019). The operational risk management aims to identify the banks that suffer from these risks, in order to make sound decisions that help the companies in dealing with risks and responding to them (Rahim, Ahmed \& Faiq, 2018). It may be caused by the failure of the system associated with the bank or the people who are not sufficient experience in dealing with these risks.

There are several kinds of risks that may have an unavoidable and negative impact on the environmental business (Hashim, Ahmed, \& Huey, 2019). Banking risk management has thrived in four main areas; risk identification, risk control, risk analysis, risk assessment. They are as a core and pillars that are useful to limit the negative impact on the banks. Today's increasingly competitive environment depends on service quality and customer satisfaction with the effective management of operational risks (Fernando, \& Saravannan, 2021; Shaharudin, Fernando, Ahmed, \& Shahudin, 2020; Mohter, \& Fernando, 2020). Customer satisfaction is a tool for achieving sustainable, high-performance banking services (Arhenful, Yeboah, \& Tackie, 2019). The degree of risk varies from one bank to another, and on this basis, managing or controlling these risks or limiting their consequences has become one of the most important responsibilities should be taken into considerations in all institutions. For the context of the current research, Oman banks today have faced many operational risks when conducting banking business and these risks may also lead to unclear future results. Such banks are suffering from financial problems and risks which are cannot be ignored (Gani, Al Rahbi, \& Ahmed, 2021; Alyaarubi, Alkindi, \& Ahmed, 2021; Sapuan, Wahab, Sholihin, \& Sawaluddin, 2020). Therefore, it is necessary to know the appropriate methods to manage these risks in order to achieve the objectives of the banks to monitor the level of risks around the business and to control the negative impact effected by these risks.

Due to excessive operational risk, banks bear the losses that incur, so banks have to manage these risks. Moreover, banks with excessive ranges of operational risks can incur huge losses in dealing with them. In addition to receiving complaints from customers, managers need to access the substance of these complaints and evaluate customer satisfaction (Rahim, Ahmed, \& Faeeq, 2018). Performing digital optimization will increase the operational risks of the financial 
institution and avoid potential losses that harm the financial institution's objectives (Thottoli, Thomas, \& Ahmed, 2019a; Alsulmani, Alkindi, \& Ahmed, 2021; Thottoli, Thomas, \& Ahmed, 2019a). There are also consumer risks that occur as a result of human resources whether they are employees or senior employees. Such risks may also related to absenteeism and internal fraud. For example, the inability to assume key positions. Where banks are exposed to the presence of many operational risks and customer complaints, for example:

- Financial fraud and embezzlement.

- Forgery, which consists of counterfeiting assessments and documents.

- Mistakes made through personnel lead to dangers due to negligence or lack of experience.

- Counterfeiting of currencies.

- Lack of appreciation when closing bills and negligence in opening accounts.

- Cybercrimes ensuing from the technological improvement and more than a few strategies in banking transactions, as properly as blunders ensuing from the failure of technical tools used in banks.

- The popularity of the bank: As an end result of terrible rumors that the financial institution is uncovered to, the bank's revenues may additionally limit and clients may additionally lose.

Omani financial institutions focus on how to detect, measure and manage these operational risks. This research focuses on identifying problems in managing operational risks. Reviewing and analyzing customer complaints and reducing the risks that Oman banks face because work in the bank is not without risks, and further customer complaints are still continuing. Based on the above explanation, the aim of current research is to examine the relationship between operational risk management and customer complaints in banks. The next sections starts with the literature review regarding operational risk management and customers complaints, research framework, methodology, results. The remainder of this research consists of a discussion the impact operational risk management on customers complaints, conclusion and recommendation this research.

\section{CRITICAL REVIEW OF THE LITERATURE}

In this section, the emphasis will be placed on previous research in the last five years. Most of the research has determined that managing operational risks and customer complaints, for example, Neifar, Salhi, and Jarboui, (2020) were tested the economic impact on disclosure of performance, operational risks, as well as the interactions with Shariah supervision of banks. The primary finding of this study is that Sharia Supervisory Board performance, disclosure, or relationship to Board Effectiveness. Even if the overall performance improves, the requirements for disclosure or reporting on the actual situation of stakeholders in the bank must be complied with. Zouari, and Abdelmalek, (2020) studied the operational situation for risk management between monetary innovation and the general performance of banks in Tunisia the results showed that the continuous improvement of the market for Bursa Banks through economic innovation depends on the operational position in managing risks. Rahim et al, (2019) verified the link between operational risk management and customer complaints in Malaysia. The results of this research discovered that operational risk management factors have a significant negative association with customer complaints. The significance of lookup lies in examining the influence of credit and risk management on the overall performance of Indonesian banks (Saiful and Ayu, 2019). As a result of this research, operational risk management has a beneficial effect on the overall joint performance of Indonesian banks. Arhenful, Yeboah and Tackie, (2019) studied an experimental assessment of operational risk management for Ghanaian industrial banks using descriptive disparity to find out the statistics obtained from 32 banks. They found that there is minimal awareness of the basic requirements of operational risks and the absence of systematic opportunity identification strategies. In addition, monitoring methods and technologies are no longer highquality in Ghana's commercial banks. Commercial banks are inspired to inculcate a risk-sensitive lifestyle and opportunities to define monitoring mechanisms. Therefore, appropriate assessment can be used to manage the operational risks of the bank as a channel to mitigate the risks. The correlation between the financial institution's internal controls system and the management of operational risks was examined by Rahim et al, (2018). The traditional Malaysian banks have a correct internal supervision tool that controls operational risks. Kordlouie, Sadeghi and Sadeghi, (2018) aimed to identify the impact of risk management on the fluctuations in profits of shares of banks listed in Tehran. They confirmed that the risk management aspect was 0.002 and showed that the risk factors have a tremendous negative impact. Hence, they proposed two hypotheses linked to the assumptions: firstly, risk management has a significant impact on the volatility of financial institutions' earnings and secondly, the dividend yield has a greater impact on the volatility of Bank of Tehran's earnings. Anastasovksi, (2018) discussed banking and operational risks, which includes a simplified map of several categories of operational risks as well as the usage of gap analysis as a useful technique for assessing controllable risks.

Trung, Hsiao, Shen and Chen, (2018) were tested the relationship between the bank's operating risks and overall performance in Taiwan was investigated. They found that cost inefficiency leads to lower financial efficiency. Salim, Setiawan, Rofiaty and Rohman, (2018) the cause for this research is to study consumer complaints, provide an explanation and deal with them, and the impact of quality from banking service providers on the customer's loyalty to the bank. If customers are no longer satisfied, they tend to focus attention on resolving complaints to reap customer satisfaction. Rahim et al, (2018) focused on examining the standard to establish sound management of operational risks in banks. And to know the relationship between internal control systems and business risk managers. Oluwagbemiga, Isaiah and Esiemogie, (2016) were examined the link between risk management practices and economic performance in Nigerian and they reveal that the consequences of trends in risk management practices for various developing economies. 
Korableva, and Kalimullina, (2016) were searched to endorse a new banking system risk management apparatus. Subsequently they found a new technique for risk management in the Russian banking institution required, because the Russian banking system faces many risks along with operational risks, which has led to great interest in managing operational risks. They also proposed a superior methodology for risk management that depends entirely on the analysis of Strengths Weaknesses Opportunity Threat and Balanced Scorecard. Safari, Shateri, Baghiabadi, and Hozhabrnejad, (2016) conducted a study on managing the operational risks of various banks and monetary institutions. They reviewed the literature on sound risk management in banks and concludes that failure to deal with risks will have a negative impact on banks. Additionally, executives speculated that the unwavering interest in managing risk no longer just avoided losses but could additionally be a skill to gain a competitive advantage. Sharifi, Haldar and Rao, (2016) were attempted to analyze the relationship between operational risk management and the size and ownership of Indian banks and the results show that the dimensions of Indian banks are inversely proportional to surplus capital to control operational risk. likewise, there is no statistically significant relationship between ownership (public, private, and foreign) and the additional capital that banks hold to manage operational risk. Antony, (2016) were focused customer complaints have become about banking services, complaints management is the process of listening to unhappy customers with the problem of the bank's system and taking measures to address complaints and problems and showed that all banks have formal practices for dealing with these complaints. Neifar Salhi, and Jarboui, (2020) found that the quality of Shariah Supervisory Board (SSB) performance or disclosure or relationship with BE appears to indicate that it has a higher level of SSB quality, even if performance improves, introducing brokers must comply with disclosure or reporting requirements on the real situation of stakeholders in the bank. Sleimi et al. (2020) were try to show an understanding of risk management and has found that risk management has a positive impact on the performance of banks. Therefore, risk identification has little effect on banks' performance. Zouari et al. (2020) were identified that the continuous improvement of the bank's stock market through financial innovation depends on the operational role in risk management. Saiful et al. (2019) were also found that operational risk management has a positive impact on banks' performance. Rahim et al. (2018) were claimed that traditional banks have a good internal supervision system that controls operational risks, and with this the performance of this system is excellent, and it can detect these risks and manage them immediately, and with this, the risks can be avoided, and positive results can be obtained for the bank.

Kordlouie et al. (2018) were suggested that risk factors have a significant negative impact on them and proposed two hypotheses related to the assumptions: firstly, risk management has a significant impact on the volatility of bank profits and secondly, the dividend yield has a greater impact on the volatility of a bank's earnings. Salim et al. (2018) research results revealed that the effect of service quality on customer loyalty can be modified through customer satisfaction and showing a positive correlation. The effect of complaints on customer loyalty can also be modified through customer satisfaction and demonstrating a positive relationship. Complaints resolution has the greatest coefficient value in achieving customer satisfaction and influencing customer loyalty. Trung et al. (2018) results shown that operational risks, when managed, will have a positive impact on cost inefficiency, and lead to lower economic efficiency. Safari et al. (2016) reviewed the literature on sound risk management in banks and concludes with the following conclusion that failure to deal with risk will have a negative impact on banks. In addition, executives expected that continued attention to risk management not only avoids losses but it can also be a means of gaining a competitive advantage.

Many nations go through these operational dangers and client complaints in the bank, however as soon as these troubles are resolved and these issues are located and addressed, it will lead to effective consequences for the banking system. In addition, relying on the right approach of managing the operational dangers that the financial institution chooses primarily based on a collection of elements and deciding on gorgeous options to tackle them. However, there are additionally poor penalties that deliver operational dangers to the bank. These bad penalties solely show up when these dangers are left out or no longer addressed. Through research and outcomes that have proven that the positive relationship prevailed over the negative relationship due to the fact when these dangers are managed properly and additionally when they are detected early and treated, the bank's role will enhance for the better. The following is a nice correlation between operational hazard administration and client complaints in the bank. Managing, controlling, and resolving these dangers influences the overall performance of clients and they sense cozy doing the work with excellent overall performance and with the result except any complaints.

\section{RESEARCH FRAMEWORK}

The theoretical framework of this study provides the underlying structure regarding the dependent variable (customer complaints), and the independent variable (operational risk management). Logically, a theory was developed to describe the correlation between variables for a complete literature review survey. And then improving the research hypotheses to answer the research questions related to the study. Figure 1. below presents the proposed research framework of this study. Operational risk management is the independent variable and customer complaints are the dependent variable. 


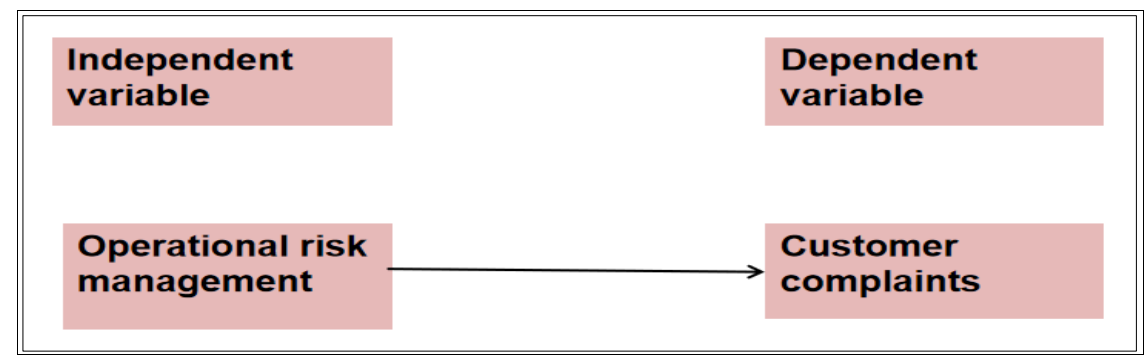

Figure 1. Schematic Diagram of Research Framework

\section{METHODOLOGY}

This is a cross-sectional study using qualitative methods, in which qualitative data is collected through primary data. The dependent variable in this study is customer complaints. The factors affecting profit management are also called independent variables operational risk management. For this research, the population of this study will be bank customers who are currently in Oman. In this study, a sample size of 8. This study examines the relationship between operational risk management and customer complaints and uses the questionnaire for analysis. The analysis units for this study, where the questionnaire (Adapted from Rahim, Ahmed, \& Faeeq, (2018)) was used for some employees working in Omani banks and who have knowledge of the nature of the bank's system for the year 2020. In this research, data gathered is analyzed with Structural Equation Modeling (SEM) with Partial Least Square (PLS) approach. This study used a set of survey tools containing questionnaires to measure the variables.

\section{RESULTS}

\section{Response Rate}

Based on Table 1, 51.7\% of respondents are female and $48.3 \%$ are male. Moreover, $56.7 \%$ of the respondents have a bachelor's degree, $3.3 \%$ of them hold a master's degree and $40 \%$ have a diploma. In addition, $41.7 \%$ of the respondents were between the ages of 30 to 39 years, while $3.3 \%$ were in the age range of 46 to 50 years. Regarding the branch size, $35 \%$ of the respondents are from a small branch, while $31.7 \%$ are from a large branch, and $33.3 \%$ are from a medium branch. Also, $35 \%$ of branches include the foundation years within 11 to 15 years while $10 \%$ within 1 to 5 years. $58.3 \%$ of the respondents work in the branch within 6 to 10 years, while $1.7 \%$ work in the branch within 16 years and above, and $8.3 \%$ have worked in the branch for less than five years.

Table 1. Demographic Profiles of Respondents.

\begin{tabular}{|c|c|c|}
\hline Demographics & Percent & Frequency \\
\hline \multicolumn{3}{|l|}{ Gender } \\
\hline Male & 48.3 & 29 \\
\hline \multirow[t]{2}{*}{ Female } & 51.7 & 31 \\
\hline & 100.0 & 60 \\
\hline \multicolumn{3}{|l|}{ Education } \\
\hline Diploma & 40 & 24 \\
\hline Bachelor Degree & 56.7 & 34 \\
\hline \multirow[t]{2}{*}{ Master Degree } & 3.3 & 2 \\
\hline & 100.0 & 60 \\
\hline \multicolumn{3}{|l|}{ Age } \\
\hline $21-29$ & 35 & 21 \\
\hline $30-39$ & 41.7 & 25 \\
\hline $40-45$ & 20 & 12 \\
\hline \multirow[t]{2}{*}{$46-50$} & 3.3 & 2 \\
\hline & 100.0 & 60 \\
\hline \multicolumn{3}{|l|}{ Branch Size } \\
\hline Small & 35 & 21 \\
\hline Medium & 33.3 & 20 \\
\hline \multirow{3}{*}{$\begin{array}{r}\text { Total } \\
\text { Years of Branch Established }\end{array}$} & 31.7 & 19 \\
\hline & 100.0 & 60 \\
\hline & \multicolumn{2}{|c|}{ Years of Branch Established } \\
\hline $1-5$ years & 10 & 6 \\
\hline $6-10$ years & 33.3 & 20 \\
\hline $11-15$ years & 35 & 21 \\
\hline \multirow[t]{2}{*}{16 and above } & 21.7 & 13 \\
\hline & 100.0 & 60 \\
\hline
\end{tabular}




\begin{tabular}{|c|c|c|}
\hline Demographics & Percent & Frequency \\
\hline \multicolumn{3}{|l|}{ Years in Branch } \\
\hline Less than 5 years & 8.3 & \\
\hline 6-10 years & 58.3 & 35 \\
\hline $11-15$ years & 31.7 & 19 \\
\hline 16 years and above & 1.7 & 1 \\
\hline Total & 100.0 & 60 \\
\hline
\end{tabular}

Based on Table 2, 51.7\% is represented the percentage of the working respondents that belong to Bank Muscat which is the highest percentage, while for Dhofar Bank, it is 11.7\% . Also the National Bank of Oman it is 10.0\% and Qatar National Bank is 3.3\% of respondents employed.

Table 2. Respondents from Banks.

\begin{tabular}{lr}
\hline Name of Bank & Percentage \\
\hline Muscat Bank & $51.6 \%$ \\
Dhofar Bank & $11.7 \%$ \\
National Bank of Oman (NBO) & $10.0 \%$ \\
Oman Arab Bank (OAB) & $5.0 \%$ \\
Bank Shoar & $8.3 \%$ \\
Ahli Bank & $5.0 \%$ \\
HSBC Oman Bank & $5.0 \%$ \\
National Bank Of Qatar & $3.3 \%$ \\
\hline
\end{tabular}

\section{Descriptive Statistics}

Firstly, based on the results of the descriptive statistics in Table 3, the independent variable of risk identification shows that the branch has a classification of operational risks according to their effects and urgency (Hazard Identification-8), and the responses of the respondents were between 5 (strongly agree) and 1 (strongly disagree) with a standard deviation 0.836 . The branch also carried out a comprehensive and systematic identification of the risk related to each of its goals and objectives (Hazard Identification-6), and respondents' responses were maximum of 5(strongly agree), and a minimum3 (normal). Secondly, in risk analysis the respondents' opinions were between a maximum of 5 (strongly agree) and a minimum of 2,3 , and 1 , and the lowest value of the standard deviation is 0.586 , and this value is good because the lower the value of the standard deviation, the better. Thirdly, analysis of risk control measures most of the respondents had their opinions at a minimum of 1 (strongly disagree), a maximum of 5 (strongly agree), and a minimum standard deviation of 0.611 .

In addition to that, the branch measures the operational risks according to the procedures determined by the higher management (Analyze Risk Control Measures-2). Here, the highest value of the standard deviation was obtained 0.894, and the mean was 4.967. Fourthly, Control decision here the branch manager conducts monthly surprise checks on the branch's operations, and the results are between 3 (neutral) and 5 (strongly agree) and mean 4,250. Fifthly, Implementation of risk controls where the branch sets policies to help in implementing risk controls effectively, with a standard deviation of 0.706, so the respondents' response (Implementation on Risk Control-1) was between 2 (disagree) and 5 (agree Strongly), the branch also performs the application of operational risk control with a standard deviation of 0.671 , so the respondents' response (Implementation on Risk Control-5) was between 2 (disagree ) and 5 (strongly agree). Sixthly, the resulting variable was shown by supervising whereby the branch employees manage individual operational risks with a standard deviation of 0.718 , so the respondents' response was (Supervise-4) between 1 (strongly disagree) and 5 (strongly agree). The branch also has a system for reporting risk management that the branch faces with a standard deviation of 0.655 , so the respondents' response (Supervise-5) was between 2 (disagree) and 5 (strongly agree). Moreover, the number of respondents agreed to manage and report operational risks.

Based on the descriptive census results in Table 3, the dependent result of customer complaints showed that the balance recovered from the branch did not agree with the customer's account or recorded it with a standard deviation of 0.661, so the respondents (Customer Complaints-6) was between 2 (frequently) and 5 (never). Also, the inability to withdraw funds to dormant accounts with a standard deviation of 0.624, so the respondents (Customer Complaints-7) were between 3 (occasionally) and 5 (never) and the mean 4.100. Moreover, the number of respondents agreed that the hidden balance does not agree with the customer's account.

Table 3. Descriptive Statistics.

\begin{tabular}{rrrrr}
\hline & Mean & Minimum & Maximum & \multicolumn{1}{c}{ Standard-D } \\
\hline HI-1 & 3.950 & 1.000 & 5.000 & 0.865 \\
HI-2 & 3.717 & 1.000 & 5.000 & 0.915 \\
HI-3 & 3.867 & 2.000 & 5.000 & 0.806 \\
HI-4 & 4.100 & 1.000 & 5.000 & 0.810 \\
HI-5 & 4.217 & 2.000 & 5.000 & 0.732 \\
HI-6 & 4.167 & 3.000 & 5.000 & 0.711
\end{tabular}




\begin{tabular}{|c|c|c|c|c|}
\hline & Mean & Minimum & Maximum & Standard-D \\
\hline HI-7 & 4.167 & 2.000 & 5.000 & 0.799 \\
\hline HI-8 & 4.033 & 1.000 & 5.000 & 0.836 \\
\hline HI-9 & 4.417 & 3.000 & 5.000 & 0.586 \\
\hline RA-1 & 4.300 & 3.000 & 5.000 & 0.714 \\
\hline RA-2 & 4.033 & 1.000 & 5.000 & 0.774 \\
\hline RA-3 & 4.183 & 2.000 & 5.000 & 0.719 \\
\hline RA-4 & 4.017 & 1.000 & 5.000 & 0.764 \\
\hline RA-5 & 4.233 & 3.000 & 5.000 & 0.667 \\
\hline RA-6 & 4.100 & 2.000 & 5.000 & 0.790 \\
\hline RA-7 & 4.350 & 3.000 & 5.000 & 0.628 \\
\hline ARCM-1 & 4.183 & 2.000 & 5.000 & 0.785 \\
\hline ARCM-2 & 4.967 & 1.000 & 5.000 & 0.894 \\
\hline ARCM-3 & 3.133 & 2.000 & 5.000 & 0.785 \\
\hline ARCM-4 & 4.167 & 2.000 & 5.000 & 0.711 \\
\hline ARCM-5 & 4.183 & 3.000 & 5.000 & 0.645 \\
\hline ARCM-6 & 4.400 & 3.000 & 5.000 & 0.611 \\
\hline CONT-D-1 & 4.283 & 2.000 & 5.000 & 0.709 \\
\hline CONT-D-2 & 4.133 & 2.000 & 5.000 & 0.591 \\
\hline CONT-D-3 & 4.167 & 3.000 & 5.000 & 0.687 \\
\hline CONT-D-4 & 4.117 & 2.000 & 5.000 & 0.685 \\
\hline CONT-D-5 & 4.250 & 3.000 & 5.000 & 0.595 \\
\hline IR-CONT-1 & 4.250 & 2.000 & 5.000 & 0.706 \\
\hline IR-CONT-2 & 4.367 & 1.000 & 5.000 & 0.732 \\
\hline IR-CONT-3 & 4.117 & 3.000 & 5.000 & 0.619 \\
\hline IR-CONT-4 & 4.183 & 2.000 & 5.000 & 0.741 \\
\hline IR-CONT-5 & 4.183 & 2.000 & 5.000 & 0.671 \\
\hline SUP-1 & 4.317 & 2.000 & 5.000 & 0.706 \\
\hline SUP-2 & 4.167 & 2.000 & 5.000 & 0.711 \\
\hline SUP-3 & 4.067 & 2.000 & 5.000 & 0.793 \\
\hline SUP-4 & 4.133 & 1.000 & 5.000 & 0.718 \\
\hline SUP-5 & 4.267 & 2.000 & 5.000 & 0.655 \\
\hline CUS-COM-1 & 4.500 & 2.000 & 5.000 & 0.619 \\
\hline CUS-COM-2 & 4.950 & 2.000 & 5.000 & 0.617 \\
\hline CUS-COM-3 & 4.200 & 3.000 & 5.000 & 0.600 \\
\hline CUS-COM-4 & 4.033 & 2.000 & 5.000 & 0.632 \\
\hline CUS-COM-5 & 4.167 & 1.000 & 5.000 & 0.756 \\
\hline CUS-COM-6 & 4.117 & 2.000 & 5.000 & 0.661 \\
\hline CUS-COM-7 & 4.100 & 3.000 & 5.000 & 0.624 \\
\hline CUS-COM-8 & 4.300 & 3.000 & 5.000 & 0.640 \\
\hline CUS-COM-9 & 4.183 & 2.000 & 5.000 & 0.671 \\
\hline
\end{tabular}

\section{Discriminant Validity}

In the PLS to set discriminatory power, there are criteria applied. The square root of each AVE for each structure should have a high correlation level including other combinations. And also, to prove discriminatory validity through evidence that measures of constructors should not, in theory, be closely related to each other.

Table 4. Discriminant Validity Constructs

\begin{tabular}{lrrrrrrr}
\hline & ARCM & CONT-D & CUS-COM & HI & IR-CONT & RA & SUP \\
\hline ARCM & 0.423 & & & & & & \\
CONT-D & 0.375 & 0.486 & & & & & \\
CUS-COM & 0.438 & 0.409 & 0.412 & & & & \\
HI & 0.183 & 0.542 & 0.404 & 0.435 & & & \\
IR-CONT & 0.373 & 0.307 & 0.408 & 0.308 & 0.501 & & \\
RA & 0.438 & 0.462 & 0.519 & 0.348 & 0.236 & 0.373 & \\
SUP & 0.423 & 0.033 & 0.513 & 0.206 & 0.244 & 0.377 & 0.499 \\
\hline
\end{tabular}

The structural model analysis is performed once the measurement model has been analyzed and has passed all criteria. The test associated with the coefficient of determination $\left(\mathrm{R}^{2}\right)$ has been completed. During this work, the dependent variable that is customer complaints is shown to have an $\mathrm{R}^{2}$ of 0.523 . 
Table 5. Explanation of the Variance

\begin{tabular}{crr}
\hline Matrix & R Square & R Square A \\
\hline CUS-COM & 0.523 & 0.469 \\
\hline
\end{tabular}

\section{Hypothesis Testing}

Table 6, reviews the results for hypothesis testing and finds that the majority of the hypotheses are not supported (Support only one hypothesis) the results presented that (the Operation Risk Management (with supervision) positively significant with customer complaint) where it was $\mathrm{P}<0.007, \mathrm{t}=2.696$. This result indicates that (Operation Risk Management has a positive impact on customer compliance).

The findings showed (Analyze Risk Control Measures) positive and insignificant with customer complaint where it was $\mathrm{P}<0.165, \mathrm{~T}=1.391$. And (Control Decision) where it was $\mathrm{P}<0.494, \mathrm{t}=0.685$. And (Hazard identification) where it was $\mathrm{P}<0.446, \mathrm{t}=0.762$. (Implementation of Risk control) where it was $\mathrm{P}<0.483, \mathrm{t}=0.701$. (Risk analysis) where it was $\mathrm{P}<0.459$, $\mathrm{t}=0.741$. All these findings are positive and insignificant.

Table 6. Path Coefficients.

\begin{tabular}{lcccccc}
\hline & $\begin{array}{c}\text { Original } \\
\text { Sample }\end{array}$ & $\begin{array}{c}\text { Sample } \\
\text { Mean (M) }\end{array}$ & $\begin{array}{c}\text { Standard } \\
\text { Deviation }\end{array}$ & $\begin{array}{c}\text { T } \\
\text { (O/STDEV) }\end{array}$ & $\begin{array}{c}\text { Statistics } \\
\text { P Values }\end{array}$ & $\begin{array}{c}\text { Original } \\
\text { Sample }\end{array}$ \\
\hline ARCM -> CUS-COM & 0.224 & 0.134 & 0.161 & 1.391 & 0.165 & 0.224 \\
CONT-D -> CUS-COM & 0.147 & 0.090 & 0.215 & 0.685 & 0.494 & 0.147 \\
HI -> CUS-COM & 0.120 & 0.202 & 0.158 & 0.762 & 0.446 & 0.120 \\
IR-CONT -> CUS-COM & 0.115 & 0.077 & 0.164 & 0.701 & 0.483 & 0.115 \\
RA -> CUS-COM & 0.139 & 0.231 & 0.188 & 0.741 & 0.459 & 0.139 \\
SUP - > CUS-COM & 0.384 & 0.283 & 0.142 & 2.696 & 0.007 & 0.384 \\
\hline
\end{tabular}

Note: Significance levels: $* * * \mathrm{P}<0.001(\mathrm{t}>3.33),{ }^{*} \mathrm{p}<0.01(\mathrm{t}>2.33),{ }^{*} \mathrm{p}<0.05(\mathrm{t}>1.605)$

\section{IMPACT OF OPERATIONAL RISK MANAGEMENT ON CUSTOMER COMPLAINTS}

The main objective of this research is to determine the relationship between operational risk management and customer complaints in Omani banks. This research used a questionnaire, and the total of the responses is 60, and hypotheses were made to inquire about the target. This analysis identifies five variables that affect operational risk management, which are the independent factor variables (risk identification, risk analysis, analysis of risk control procedures, control decision, implementation of risk controls). As for the variable that affects customer complaints, which is the dependent factor variable (supervision).

Recently, emphasis has been placed on the importance of proper operation in risk management in banks, and these economic institutions can now perceive the risks and document them in order to implement excellent strategies for them. But operational risk can also be seen as the weakness of monetary institutions, especially this type of risk can be reduced and eliminated by senior management; Lack of management will result not good for operational risk causing chaos and thus leading to failure of the financial institution. However, there are many types of complaints about offers made by the financial institution from cashiers, which include transaction posting errors and unauthorized withdrawals. Therefore, customers' negligence in executing the transactions will make them vulnerable, due to the fact that operational errors will appear during the course of the transaction, which will lead to increased expenses to reduce the subsequent dire consequences.

Analyze risk control measure: This is one of the independent variables associated with the management of operational risks, and the results showed a positive significant relationship with customer complaints where $(p>0.165, t=1.39)$. This result consistent with the study done by Sleimi (2020) found a positive impact on the bank's performance in terms of risk analysis and also through continuous monitoring and monitoring of risks. That is mean high mange of risk will lead to reduce customer complaints. Control decision: From the independent variables associated with operational risk management where the results showed a positive significant relationship with customer complaints where $(\mathrm{p}<0.494, \mathrm{t}=$ 0.685). This result is consistent with a study by Trung et al, (2018) where there is a positive relationship when administered on cost inefficiency and leads to Low economic efficiency. That is mean when administered of cost inefficiency will lead to low economic efficiency and complaints. Hazard identification: This is one of the independent variables associated with operational risk management as the results represented a positive significant relationship with customer complaints $(\mathrm{P}<0.446)(\mathrm{t}=0.762)$. This finding correlates with the previous study of Arhenful, et al, (2019) that there is a positive correlation from identifying risks and understanding the basic requirements for operational risks, effective risk monitoring and control methods for commercial banks are also being developed. This means that when understanding the basic requirements of operational risk and developing effective methods of monitoring and control, customers' complaints will be reduced in banks.

Supervision: This is an independent variable, as the results showed a supported positive relationship with customer complaints $(\mathrm{P}<0.007, \mathrm{t}=2.696)$. This result is consistent with a study (Rahim, et al, 2019) to test the link between operational risk management and customer complaints, and it was found that the elements of operational risk management have a positive effect while customer complaints have a negative effect. This means that the link between operational risk management and customer complaints will lead to an increase in risk management and thus fewer customer complaints. 
Implementation of risk controls: From the independent variables associated with operational risk management where the results showed the existence of a positive significant relationship with customer complaints $(\mathrm{p}<0.483, t=0.701)$. This result is consistent with a study done by Rahim et al, (2018) to establish sound management standards for operational risks in banks and to discover the relationship between Internal control systems and business risk managers. This means that when risk measures are implemented to control it, customers will have fewer complaints. Risk analysis: It is also considered one of the independent factors associated with managing operational risks, and the results showed a positive significance with customer complaints $(\mathrm{P}<0.459, \mathrm{t}=0.741)$. Whereas there was a correlation of the previous study by Zouari, and Abdelmalek, (2020) a positive relationship between the independent and dependent variable in terms of managing operational risks and customer complaints, as well as the continuous improvement of banks based on the operational role in risk management and analysis. This means that when operational risks are analyzed and detected, customers' complaints will be reduced.

Additionally, Safari, et al, (2016) This paper concluded that there is a negative relationship in not handling risk, and thus it has a negative impact on banks. Also, Kordlouie, et al, (2018) concluded in this study that risk has a significant negative impact on them. Moreover, this paper proposes a hypothesis related to the assumption that risk management has a significant effect on the volatility of banks' earnings. Therefore, there is a positive and negative relationship between operational risk management and customer complaints, analysis of risk control measures, and implementation of risk control has a positive effect. While the risks that may occur in branches include errors in data, entries, and system errors that cannot be reported, including registration and control. It is important for clients to understand the strategies or tools that branches use to reduce risk, but for branches, it is also important to ensure that risks are minimized as a potential factor.

\section{RECOMMENDATION}

To enhance and improve the modern situation in combating operational risks of banks and customer complaints, plans must be taken to manage financial institutions and a mechanism for identifying, measuring, controlling, and reducing risks.

First, the development of an appropriate local climate for risk management, by adopting a common approach to managing operational risks at the bank level. The strategy will typically be reviewed to ensure that it adapts to improving the business environment so that the approach truly addresses the management of operational risk as an unbiased type of risk. The strategy should also include the level of risk. General operational risks accepted by the bank, which offer to determine the priority of the bank in managing operational risks. It also provides the employees who are primarily responsible for managing the operational risks of each bank and represent this specialized group of workers in the treatment of problems and continuous high-quality internal audits so that they can discover and identify the operational risks they face, in order to manage and control them. In addition to establishing and approving equipment and structures to measure risks and qualify employees to use them successfully to discover and deal with risks.

Secondly, reviews must be submitted to senior management through the operational risk department, the internal audit department, the relevant facts, and risk departments to identify, measure and manage operational risks, as well as the importance of disclosing these risks by the bank for the board of directors to obtain an extraordinary degree of records. To be in a position to be able to recognize the usual situation of the risks faced by the bank, focus attention on the material effects, and a diploma of adaptation to the method of the commercial enterprise to help it make appropriate decisions. The desire to keep abreast of current trends with correct and sound practices due to the fact that modern technology is evolving and employees who are equipped to use them are approved to be in a position to deal with risks and reduce them. In addition, it is preparing contingency plans ready to face any potential troubles they may face when practicing banking activities that must be performed to avoid losses.

\section{CONCLUSION}

The fundamental purpose of our mission is to examine the relationship between Operational Risk Management and Customer Complaints in Omani banks through the use of a Questionnaire. This lookup used six impartial variables (Hazard Identification, Risk Analysis, Analyze Risk Control Measures, Control Decision, Implementation of Risk Controls, and Supervise) to measure the influence of Operational Risk Management and Customer Complaints. This research used a questionnaire for the personnel of Omani banks to analyze and study the relationship between operational risk management and customer complaints. This study concluded that there is a relationship between operational hazard administration and patron complaints. Therefore, the administration of operational dangers has a high quality have an impact on the overall performance of banks, however, on the different hand, there is a bad relationship in the tournament that dangers are now not dealt with.

Many international locations go through these operational dangers and purchaser complaints in banks, however as soon as these troubles are resolved and these issues are observed and resolved, they will yield high-quality effects for the banking system. In addition to relying on the right approach of managing operational dangers that the financial institution chooses based totally on a collection of factors and deciding on gorgeous options to deal with these risks. However, there are additionally terrible consequences that convey operational dangers to the bank. These terrible penalties can solely appear when these dangers are neglected or no longer addressed. Research and consequences exhibit that the tremendous relationship is higher than the terrible relationship, due to the fact if these dangers are managed in the proper way, as properly as early detection and cure of these risks, the bank's function will improve. The following is a high-quality 
correlation between operational threat administration and client complaints in banks. Managing, monitoring, and resolving these dangers will have an effect on patron performance, as they will effortlessly work with first-class overall performance and pleasant effects except any complaints.

\section{ACKNOWLEDGEMENT}

The authors would like to thank the University of Nizwa and Dr. Essia Ries Ahmed which assist to conduct this research.

\section{REFERENCES}

Ahmed, E. R., Alabdullah, T. T. Y., Shaharudin, M. S., \& Putri, E. (2020). Further Evidence on the Link Between Firm's Control Mechanisms and Firm Financial Performance: Sultanate of Oman. Journal of Governance and Integrity, 4(1), 6-11.

Ahmed, E. R., Amran, A., \& Islam, M. A. (2018). Sukuk documentation and legitimacy: the role of shariah supervisory board as a moderator. Management, 5(3), 22-40.

Alabdullah, T. T. Y. (2019). Management Accounting and Service Companies' Performance: Research in Emerging Economies, Australasian Accounting, Business and Finance Journal, 13(4), 100-118.doi:10.14453/aabfj.v13i4.8.

Alabdullah, T. T. Y. and Ahmed, E. R. (2018). Corporate Governance: To What Extent it is important in the Arab Countries. International Journal of Science and Research 7.

Alfadhl, M. M. A., Alabdullah, T. T. Y. (2016). Agency Cost and Management Behavior: The Role of Performance as a Moderator. International Journal of Science and Research (IJSR), 5(1), 1858-1864.

Alabdullah, T. T. Y \& Ahmed, E. R. \& Abushammala, S. (2020). Growth of Companies: Empirical Study of the Companies Listed in Developing Economies. Journal of accounting Science, Vol. 4, no. 2, pp. 1-10.

Alabdullah, T. T. Y. (2016). Corporate Governance from The Perspective of The Past and The Present and The Need to Fill an International Gap. Risk Governance \& Control: Financial Markets \& Institutions, 6(4).

Alabdullah, T. T. Y., Ahmed, E. R., \& Nor, M. I. (2019). Do board characteristics provide more enhancement for firm financial performance? A corporate governance perspective. New challenges in corporate governance: Theory and practice (pp. 89-91). https://doi.org/10.22495/ncpr_25.

Alsulmani, A. H., Alkindi, S. S., \& Ahmed, E. R. (2021). Customer Accounting Information and Omani Service Companies' Performance. International Journal of Finance \& Banking Studies (2147-4486), 10(2), 79-88.

Arhenful, P., Yeboah, A. K., \& Tackie, B. A. (2019). Evaluation of operational risk management of commercial banks in ghana. Advances in Management and Applied Economics, 9(4), 25-40.

Alyaarubi, H. J., Alkindi, D. S., \& Ahmed, E. R. (2021). Internal Auditing Quality and Earnings Management: Evidence from Sultanate of Oman. Journal of Governance and Integrity, 4(2), 115-124.

Anastasovksi, D. (2018). Banks operational and risk problems. In Proceedings of the International scientific and practical conference "Bulgaria of regions" (Vol. 1).

Antony, G. S. (2016). Automation to Handle Customer Complaints in Banks Using BPM Tool. Culminating Projects in Mechanical and Manufacturing Engineering. 48.

Chernobai, A., Ozdagli, A., \& Wang, J. (2021). Business complexity and risk management: Evidence from operational risk events in US bank holding companies. Journal of Monetary Economics, 117, 418-440.

Fernando, Y., \& Saravannan, R. (2021). Blockchain Technology: Energy Efficiency and Ethical Compliance. Journal of Governance and Integrity, 4(2), 88-95.

Gani, A. A. M. O., Al Rahbi, A. H. S. S., \& Ahmed, E. R. (2021). Empirical Analysis on Corporate Transparency, Competitive Advantage, and Performance: An Insight of Muscat Securities Market. Journal of Governance and Integrity, 4(2), 96-102.

Hashim, F., Ahmed, E. R., \& Huey, Y. M. (2019). Board Diversity and Earning Quality: Examining the Role of Internal Audit as a Moderator. Australasian Accounting, Business and Finance Journal, 13(4), 73-91.

Kordlouie, H., Sadeghi, L., \& Sadeghi, N. (2018). An investigation on the effect of risk management on earnings volatility for shares of banks listed in Tehran Stock Exchange. Accounting, 4(3), 123-128.

Mohter, N., \& Fernando, Y. (2020). Corporate Governance and Low Carbon Supply Chains: Why Integrity Matters?. Journal of Governance and Integrity, 3(2).

Neifar, S., Salhi, B., \& Jarboui, A. (2020). The moderating role of Shariah supervisory board on the relationship between board effectiveness, operational risk transparency and bank performance. International Journal of Ethics and Systems, Vol. 36 No. 3 , pp. 325-349.

Oluwagbemiga, O. E., Isaiah, O. O., \& Esiemogie, I. P. (2016). The relationship between the risk Procedia management practices and financial performance of the Nigerian listed banks. Accounting and management Information systems, 15(3), 565.

Rahim, N. F. A., Ahmed, E. R., \& Faeeq, M. K. (2018). Internal Control System and Perceived Operational Risk Management in Malaysian Conventional Banking Industry. Global Business \& Management Research, 10(1),135-149.

Rahim, N. F. A., Ahmed, E. R., Sarkawi, M. N., Jaaffar, A. R., \& Shamsuddin, J. (2019). Operational risk management and customer complaints: the role of product complexity as a moderator. Benchmarking: An International Journal. Vol. 26 No. 8, pp. 24862513.

Saiful, S., \& Ayu, D. P. (2019). Risks management and bank performance: The empirical evidences from indonesian conventional and islamic banks. International Journal of Economics and Financial Issues, 9(4), 90.

Safari, R., Shateri, M., Baghiabadi, H. S., \& Hozhabrnejad, N. (2016). The significance of risk management for banks and other financial institutions. International Journal of Research-Granthaalayah, 4(4), 74-81.

Salim, A., Setiawan, M., Rofiaty, R., \& Rohman, F. (2018). Focusing on Complaints Handling for Customer Satisfaction and Loyalty: The Case of Indonesian Public Banking. European Research Studies Journal, 21(3), 404-416.

Sapuan, N. M., Wahab, N. A., Sholihin, M., \& Sawaluddin, S. (2020). Human Governance and Firm Success from Western And Islamic Perspectives. Journal of Governance and Integrity, 4(1), 56-63.

Shaharudin, M. S., Fernando, Y., Ahmed, E. R., \& Shahudin, F. (2020). Environmental NGOs Involvement in Dismantling Illegal Plastic Recycling Factory Operations in Malaysia. Journal of Governance and Integrity, 4(1), 29-36.

Sharifi, S., Haldar, A., \& Rao, S. N. (2016). Relationship between operational risk management, size, and ownership of Indian 
banks. Managerial Finance, Vol. 42 No. 10, pp. 930-942.

Sleimi, M. (2020). Effects of risk management practices on banks' performance: An empirical study of the Jordanian banks. Management Science Letters, 10(2), 489-496.

Thottoli, M. M., Thomas, K. V., \& Ahmed, E. R. (2019a). Adoption of audit software by audit firms: a qualitative study. Journal of Information and Computational Science, 9(9), 768-776.

Thottoli, M. M., Thomas, K. V., \& Ahmed, E. R. (2019b). Qualitative analysis on information communication technology and auditing practices of accounting professionals. Journal of Information and Computational Science, 9(9), 529-537.

Trung, M., Hsiao, C. L., Shen, D. B., \& Chen, B. S. (2018). Impact of operational risk toward the efficiency of banking-evidence from Taiwan's banking industry. Asian Economic and Financial Review, 8(6), 815-831.

Uddin, M. M., \& Khan, M. A., \& Mohammad, K. D. (2015). Interest-free banking in Bangladesh: a study on customers' perception of uses and awareness. Abasyn Journal of Social Sciences, 8(1), 1-16.

Uddin, M. M., Khan, M. A., \& Farhana, N. (2014). Banking services and customer perception in some selected commercial banks in Bangladesh. Indonesian Management and Accounting Research, 13(1), 1-15.

Zouari, G., \& Abdelmalek, I. (2020). Financial Innovation, Risk Management, and Bank Performance. Copernican Journal of Finance \& Accounting, 9(1), 77-100.

\section{CONFLICT OF INTEREST}

The author(s), as noted, certify that they have NO affiliations with or involvement in any organisation or agency with any financial interest (such as honoraria; educational grants; participation in speakers' bureaus; membership, jobs, consultancies, stock ownership, or other equity interest; and expert testimony or patent-licensing arrangements), or nonfinancial interest (such as personal or professional relationships, affiliations, expertise or beliefs) in the subject matter or materials addressed in this manuscript. 


\section{AUTHORS' BIOGRAPHY}

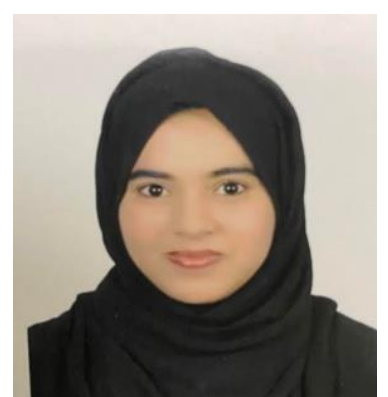

Author's Full Name: Rawan Khamis AL-kiyumi

Author Professional Bio:

The author is interested in auditing, and accounting research areas.

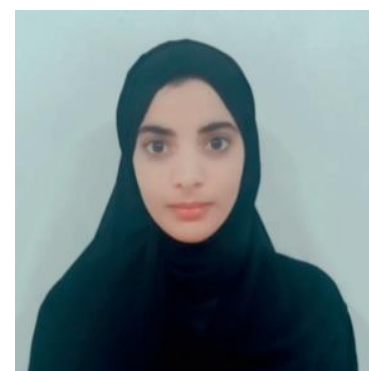

Author's Full Name: Zamzam Nasser AL-hattali

Author Professional Bio:

The author is interested in auditing, and accounting research areas.

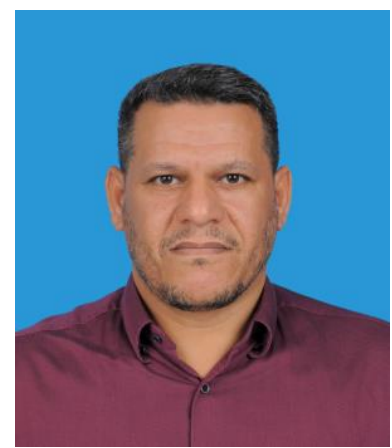

Author's Full Name: Essia Ries Ahmed

Author Professional Bio:

Dr. Essia Ries Ahmed is currently working as an assistance of Professor in University of Nizwa. He received his PhD from University Malaysia Perlis (UniMap), master's degree in Accounting from Universiti Sains Malaysia (USM).He has published articles in several Scopus Journals, and proceedings and presented papers at both national and international conferences. Dr. Essia Ries Ahmed is the reviewer and member of editorial board in several journals. 